\title{
Physicochemical Analysis of Some Table Water in Bauchi Metropolis
}

\author{
Shibdawa, M.A ${ }^{1}$ Ushie O.A. ${ }^{2}$, Okpaegbe U.C. ${ }^{2}$, Oragwa, $\mathbf{J}^{1}$ \\ ${ }^{1}$ Chemistry Programme, Abubakar Tafawa Balewa University Bauchi, Nigeria \\ ${ }^{2}$ Department of Chemical Science, Federal University, Wukari, Nigeria
}

*Corresponding Author: Ushie O.A, Department of Chemical Science, Federal University, Wukari, Nigeria

\begin{abstract}
Abs tract: This was carried out to assess quality of sachet water in Bauchi State. Six different brands of sachet water vended by street sellers in Yelwa Bauchi Metropolis were collected and analyzed in triplicate. The samples were assessed for their physical, chemical and bacteriological parameter using standard methods. The $\mathrm{pH}$, total dissolved solids, turbidity and conductivity were determined by instrumental methods. Chemical characteristics measured include $\mathrm{Cl}^{-}$, total hardness, which was determined using titrimetric methods. $\mathrm{NO}_{2}^{-}$, $\mathrm{Fe}, \mathrm{Cu}, \mathrm{Cr}, \mathrm{Mg}, \mathrm{Pb}, \mathrm{K}$ was determined using atomic absorption spectrophotometry (AAS) technique. Bacteriological parameters measured include total faecal coliform using membrane filtration method. All the results obtained were analyzed using simple standard statistical tools and compared with the Nigeria Standard for Drinking Water Quality and World Health Organization (WHO).pH, electrical conductivity, TDS, turbidity analyzed were all within permissible limit (of $6.5-8.5,1000 \mu \mathrm{S} / \mathrm{cm}, 500 \mathrm{mg} / \mathrm{L}$ and $5 \mathrm{NTU}$ respectively) recommended by NSDWQ and WHO (2007), while temperature were slightly above normal room temperature. The total hardness, $\mathrm{Cl}$-, and $\mathrm{NO} 2$-, were all within the recommended limit. For metals $\mathrm{Cu}, \mathrm{Mg}$, $\mathrm{K}$ were within the permissible limits, while $\mathrm{Cr}, \mathrm{Pb}$, and $\mathrm{Fe}$ were all above the recommended standard. The bacteriological parameters also met the standard.
\end{abstract}

\section{INTRODUCTION}

Water is one of the most important and most precious natural resources. It is essential in the life of all living organisms from the simplest plant and microorganism to the most complex living system; the human body. Water is combination of hydrogen and oxygen atoms, with a chemical formula $\mathrm{H}_{2} \mathrm{O}$. It is known to be the most abundant compound (70\%) covering the earth surface. It is significant due to its unique chemical and physical properties. But due to increase in human population, industrialization, use of fertilizer in agriculture and man-made activities, it is highly polluted with different harmful contaminants (Reda et al., 2016)

Regular drinking water monitoring is essential for supplying people with a high quality and healthy water that meets requirements of legal regulations. According to Asonye et al., 2007), availability of safe and reliable source of water is an essential prerequisite for sustained development. However, human population will suffer from various water borne diseases with the continuous use of contaminated drinking water. The availability of good quality water is an indispensable factor for preventing diseases and improving quality of life. Natural water contains different types of impurities which are introduced into the aquatic system by different ways such as weathering of rocks and leaching of soils, dissolution of aerosol particles from the atmosphere and from several human activities, including mining, processing and the use of metal based materials (Ipinmoroti and Oshodi, 1993; Adeyeye 1994; Asaolu, 1997). The increased use of metal-based fertilizer in agricultural revolution of the government could result in continued rise in concentration of metal pollutions in fresh water reservoir due to the water run-offs. Also faecal pollution of drinking water causes water born disease which has led to the death of millions of people. (Adefemi and Awokunmi, 2010).

Access to safe drinking water is key to sustainable development and essential to food production, quality health and poverty reduction. Safe drinking water is essential to life and a satisfactory safe supply must be made available to consumers. Water is thus becoming a crucial factor for development and the quality of life in many countries. In individual arid areas it has even become a survival factor. Therefore, water 
intended for human consumption must not contain germs or harmful chemicals; because water contaminated with microorganisms is the cause of epidemics (Reda et al., 2016). That is good drinking water is not a luxury but one of the most essential requirements of life itself. However, developing countries, like Ethiopia, have suffered from a lack of access to safe drinking water from improved sources and to adequate sanitation services. The WHO revealed that seventy five percent of all diseases in developing countries arise from polluted drinking water (Reda et al., 2016). Therefore; water quality concerns are often the most important component for measuring access to improved water sources.

Acceptable quality shows the safety of drinking water in terms of its physical, chemical and bacteriological parameters. International and local agencies have established procedures to determine biological and physicochemical quality of drinking water. The problems associated with chemical constituents of drinking water arise primarily from their ability to cause adverse health effects after prolonged periods of exposure, and of a particular concern are contaminants that have cumulative toxic properties, such as heavy metals and substances that are carcinogenic (Reda et al., 2016). Chemical elements present in ground water are derived from precipitation of organic processes that goes on in the soil and breaks down minerals in the rock through which the groundwater flows. Some of this constituent occur in significant amounts, whilst others are of minor importance or are present as trace constituent (Hamill and Bell, 1986). The major constituent include; sodium, calcium, magnesium, bicarbonate, sulphate, chloride \& silica. While the secondary constituents include; iron, strontium, potassium, carbonate, nitrate, fluoride \& boron. .

The physical aspect has to do with aesthetic value parameters such as colour, temperature, odour and taste; electrical conductivity (EC), total dissolved solid (TDS) which entails the ions (anions and cations) dissolved in the water.

In microbial analysis, the microbial contents of the water (i.e. the presence of coliform and other pathogenic bacteria) are checked using membrane filtration method. Water pollution is considered the addition of impurities to resources such as water or anything that changes its natural quality so that downstream users do not receive the natural taste of the stream (Anon, 1980). Ground water pollution may be caused by domestic and municipal sewages, industrial waste and agricultural waste.

Lack of access to safe and clean water is locked in the heart of poverty. Even though the issue of water is observed as a general problem for community, women bear the greater burden because of their social gender roles such as collecting water for their household.

According to Nigeria Standard of Drinking Water Quality (NSDWQ), drinking water must be within tolerable use limit for human consumption, above this limit can cause various health hazards such as disorder of the muscle, infertility, cancer cyanosis(blue baby syndrome), cholera, bacillary dysentery, and several other infections that affect the gastro-intestinal tract. This fact coupled with the importance of portable table water in any society makes it important that constant attention should be given to the quality of drinking water. The aim is to assess the physicochemical parameters of some table water to assess its drinking quality.

The research was carried out to assess the quality of six table water sold in Bauchi metropolis, Bauchi State. After the analysis, the two set of result were compared and finally compared with the Nigeria standard of drinking water to assess its drinking quality.

\section{Materials AND MeThods}

The present Bauchi State's southern and northern limits are demarcated by latitudes $9 \hat{\mathrm{A}}^{\circ} 30^{\prime}$ North and $12 \hat{\mathrm{A}}^{\circ} 30^{\prime}$ north, respectively, its western and eastern limits are bounded by longitudes $8 \hat{\mathrm{A}}^{\circ} 45^{\prime}$ East and $11 \hat{\mathrm{A}}^{\circ} 0$ ' east, respectively (Bauchi state 2003). These mark the points of longest and widest stretches of the state. Within these co-ordinates, however, the state's total land area covers about 49,259 sq. km. This is about $4.9 \mathrm{~m}$ ha out of Nigeria's $92.4 \mathrm{~m}$ ha (Nig, FOS, 1987). The state now has an eight-like shape, with a blotted lower region, with about two-thirds of the land area being south of latitude $11 \hat{\mathrm{A}}^{\circ} 15^{\prime} \mathrm{N}$ (Bauchi State 2013).

\subsection{Sample Collection}

Six (6) different brands of sachet water were collected. Three (3) samples each were randomly bought from street sellers and mini shops in Yelwa and some in Abubakar Tafawa Balewa University (ATBU) Bauchi metropolis, Bauchi State. Hence a total of eighteen (18) samples of sachet water were assembled. The samples were collected in good conditions (there was no visible opening on the sachet bag). The samples were taken to the laboratory within 1 hour of collection for analysis. 


\subsection{Laboratory Analysis of the Water Samples}

The Physicochemical parameters namely $\mathrm{pH}$, temperature, conductivity and total dissolve solid, turbidity, chloride, total hardness were determined using standard methods were made in triplicate (APHA, 1998).

\subsection{Determination of Metals}

Iron, Copper, Chromium, Magnesium, Lead, and potassium were determined using Atomic Absorption Spectrophotometer (AAS) method after been digested with nitric acid (Balogun et al., 2012, Musa et al., 2004.).

\subsection{Determination of Nitrite Ion}

Nitrite ion was measured using the Wagtech spectrophotometer. The sample cell was filled with water sample to a $25 \mathrm{~mL}$ mark. One sachet of nitrite powder was added to the water sample and shaken thoroughly. Another sample cell was filled with $25 \mathrm{~mL}$ of the water sample, use as the blank solution. The spectrophotometer was switched on and the programme was dialed and the wavelength was adjusted to $507 \mathrm{~nm}$. $15 \mathrm{~min}$ reaction time was set. The spectrophotometer was blanked with the blank solution. Then the nitrite ion concentrations of the various samples were determined and the readings were taken.

\subsection{Bacteriological Parameter \\ Total and Faecal Coliform de te rmination \\ Procedure}

\section{Method of Membrane Filtration}

- Water was boiled for $10 \mathrm{~min}$ and allowed to cool

- 10 spoonfuls of culture medium was added into the measuring tube using the integral spatula

- With the lid closed, it was shaken to dissolve all the powder

- The dissolved culture medium turned a bright pink colour

\subsection{Ste rilizing the Membrane Filtration}

Sampling cup was sterilized by swirling $1 \mathrm{~mL}$ of menthol to coat internal surface. Using a lighter to ignite flame, when extinguished, the funnel was inserted. The sampling cup was rinsed with little amount of sampling water before use. The lid was removed from the absorbent pad dispenser, and dispense into the Petri dish by sliding the grooved lever of the dispenser.

After dispensing, the media was poured into the absorbent pad in the Petri dish, making sure the absorbent pad has been saturated with a small excess of the media at the edge. The lid of the Petri dish was replaced to keep contents sterile and free from contamination according to Aug-oustinos et al., 1993; Aulicino and Orsini 1996; ASTM 1992.

\subsection{Preparation of the Aluminium Petri-Dishes/ Absorbent Pads}

The forceps lip was sterilized by passing them through a flame from a lighter and allow to cool. The sterilized was used to pick the white gridded filter paper and place in a membrane filter directly onto the bronze filter support disc ensuring the gridded side is faced up.

The filter funnel was inserted down to position and the water sample was poured into the filter funnel up to the $100 \mathrm{~mL}$ mark. The hand pump was connected to aid filtration of the sample. After filtration, the sterile forceps was used to remove the grid-side and placed up on the wetted growth pad in the Petri dish. The lid was covered, labeled appropriately and incubated according to Aug-oustinos et al., 1993; Aulicino and Orsini 1996; ASTM 1992.

\subsection{Counting Colonies and Recording Results}

After incubation (24hours), the Petri dish was removed and placed on a flat surface under natural light (Avoiding direct sunlight). Yellow colonies were counted and the result was recorded (Aug- oustinos et al., 1993; Aulicino and Orsini 1996; ASTM 1992).

\section{RESULT AND DISCUSSION}

\subsection{Result}

Below are the result obtained from the analyses carried out on six sachet water. 
Table1. Physical parameters

\begin{tabular}{lllllllll}
\hline Parameter & Masna & An'najeeb & Wikki & Basfrost & Sumnaye & Loyal & NSDWQ & WHO \\
\hline Conductivity & 39.60 & 20.00 & 40.60 & 140.00 & 50.30 & 170.30 & 1000 & 1000 \\
$(\mu$ S/cm) & \pm 0.50 & \pm 0.00 & \pm 0.50 & \pm 0.00 & \pm 0.57 & \pm 0.76 & & \\
T.D.S $(\mathrm{mg} / \mathrm{L})$ & 20.30 & 10.00 & 20.30 & 70.30 & 20.30 & 85.0 & 500 & 500 \\
& \pm 0.57 & \pm 0.00 & \pm 0.50 & \pm 0.57 & \pm 0.57 & \pm 0.57 & & \\
Temperature & 27.20 & 28.20 & 27.60 & 26.60 & 27.70 & 28.33 & Ambient & Ambient \\
$\left({ }^{0}\right.$ C) & \pm 0.75 & \pm 0.98 & \pm 0.70 & \pm 0.21 & \pm 0.60 & \pm 0.30 & & \\
Turbidity & 1.00 & $2.00 \pm 0.00$ & 1.00 & 0.00 & 0.00 & 0.00 & 5 & 5 \\
(NTU) & \pm 0.00 & & \pm 0.00 & \pm 0.00 & \pm 0.00 & \pm 0.00 & & \\
\hline
\end{tabular}

Table2. Chemical parameters

\begin{tabular}{|c|c|c|c|c|c|c|c|c|}
\hline Parameter & Masna & An'najeeb & Wikki & Basfrost & Sumnaye & Loyal & NSDWQ & WHO \\
\hline $\mathrm{pH}$ & $\begin{array}{l}7.87 \\
\pm 0.20\end{array}$ & $7.54 \pm 0.05$ & $\begin{array}{l}6.96 \\
\pm 0.02\end{array}$ & $\begin{array}{l}7.60 \\
\pm 0.16\end{array}$ & $7.10 \pm 0.23$ & $\begin{array}{l}8.00 \\
\pm 0.30\end{array}$ & $6.5-8.5$ & 8.5 \\
\hline $\begin{array}{l}\text { Total } \\
\text { hardness } \\
(\mathrm{mg} / \mathrm{L})\end{array}$ & $\begin{array}{l}0.00 \pm \\
0.00\end{array}$ & $0.00 \pm 0.00$ & $\begin{array}{l}2.00 \\
\pm 0.10\end{array}$ & $\begin{array}{l}40.00 \\
\pm 0.14\end{array}$ & $\begin{array}{l}15.00 \\
\pm 0.70\end{array}$ & $\begin{array}{l}20.50 \\
\pm 0.60\end{array}$ & 150 & $\begin{array}{l}\text { Not } \\
\text { specific }\end{array}$ \\
\hline $\begin{array}{l}\text { Chloride } \\
\text { (mg/L) }\end{array}$ & $\begin{array}{l}12.20 \\
\pm 0.29\end{array}$ & $16.20 \pm 0.20$ & $\begin{array}{l}9.20 \\
\pm 0.29\end{array}$ & $\begin{array}{l}17.30 \\
\pm 0.45\end{array}$ & $7.80 \pm 0.40$ & $\begin{array}{l}20.30 \\
\pm 0.40\end{array}$ & 250 & 250 \\
\hline $\mathrm{Pb}(\mathrm{mg} / \mathrm{L})$ & $\begin{array}{l}0.09 \\
\pm 0.01\end{array}$ & $0.06 \pm 0.06$ & $\begin{array}{l}0.55 \\
\pm 0.00\end{array}$ & $\begin{array}{l}0.08 \\
\pm 0.00\end{array}$ & $0.30 \pm 0.00$ & $\begin{array}{l}0.05 \\
\pm 0.05\end{array}$ & 0.001 & 0.001 \\
\hline $\mathrm{Fe}(\mathrm{mg} / \mathrm{L})$ & $\begin{array}{l}0.58 \\
\pm 0.02\end{array}$ & $0.43 \pm 0.02$ & $\begin{array}{l}0.84 \\
\pm 0.03\end{array}$ & $\begin{array}{l}0.71 \\
\pm 0.05\end{array}$ & $0.32 \pm 0.01$ & $\begin{array}{l}1.01 \\
\pm 0.02\end{array}$ & 0.3 & 0.3 \\
\hline $\mathrm{Cu}(\mathrm{mg} / \mathrm{L})$ & $\begin{array}{l}2.63 \\
\pm 0.00\end{array}$ & $0.14 \pm 0.01$ & $\begin{array}{l}0.12 \\
\pm 0.01\end{array}$ & $\begin{array}{l}4.00 \\
\pm 0.02\end{array}$ & $0.10 \pm 0.03$ & $\begin{array}{l}0.08 \\
\pm 0.04\end{array}$ & 1.0 & 1.3 \\
\hline $\mathrm{Cr}(\mathrm{mg} / \mathrm{L})$ & $\begin{array}{l}0.16 \\
\pm 0.00\end{array}$ & $0.09 \pm 0.06$ & $\begin{array}{l}0.20 \\
\pm 0.06\end{array}$ & $\begin{array}{l}0.08 \\
\pm 0.16\end{array}$ & $0.10 \pm 0.10$ & $\begin{array}{l}0.05 \\
\pm 0.08\end{array}$ & 0.05 & 0.05 \\
\hline $\mathrm{K}(\mathrm{mg} / \mathrm{L})$ & $\begin{array}{l}1.10 \\
\pm 0.00\end{array}$ & $1.00 \pm 0.00$ & $\begin{array}{l}3.40 \\
\pm 0.10\end{array}$ & $\begin{array}{l}5.90 \\
\pm 1.20\end{array}$ & $1.30 \pm 0.30$ & $\begin{array}{l}6.70 \\
\pm 0.30\end{array}$ & 12.00 & 12.00 \\
\hline $\mathrm{No}_{2}^{-}(\mathrm{mg} / \mathrm{L})$ & $\begin{array}{l}0.014 \\
\pm 0.003\end{array}$ & $\begin{array}{l}0.008 \\
\pm 0.001\end{array}$ & $\begin{array}{l}0.002 \\
\pm 0.00\end{array}$ & $\begin{array}{l}0.008 \\
\pm 0.003\end{array}$ & $\begin{array}{l}0.008 \\
\pm 0.003\end{array}$ & $\begin{array}{l}0.004 \\
\pm 0.00\end{array}$ & 0.2 & 0.2 \\
\hline $\mathrm{Mg}(\mathrm{mg} / \mathrm{L})$ & $\begin{array}{l}5.86 \\
\pm 0.06\end{array}$ & $1.70 \pm 0.02$ & $\begin{array}{l}2.90 \\
\pm 0.50\end{array}$ & $\begin{array}{l}5.13 \\
\pm 0.04\end{array}$ & $1.08 \pm 0.02$ & $\begin{array}{l}2.90 \\
\pm 0.09\end{array}$ & 30.00 & 30.00 \\
\hline
\end{tabular}

Table3. Bacteriological parameters

\begin{tabular}{lllllllll}
\hline Parameter & Masna & An'najeeb & Wikki & Basfrost & Sumnaye & Loyal & NSDWQ & WHO \\
\hline $\begin{array}{l}\text { Total } \\
\text { coliform } \\
(\mathrm{cfu} / \mathrm{mL})\end{array}$ & 0 & 0 & 0 & 0 & 0 & 0 & 10 \\
$\begin{array}{l}\text { Faecal } \\
\begin{array}{l}\text { Coliform } \\
(\mathrm{cfu} / 100 \mathrm{~mL})\end{array}\end{array}$ & 0 & 0 & 0 & 0 & 0 & 0 & 0 \\
\hline
\end{tabular}

\subsection{Discussion of Result}

\subsection{1. $\mathrm{pH}$}

The $\mathrm{pH}$ values of the water samples obtained are considered safe and acceptable as per the rating scale given by the Nigeria standard for drinking water and WHO (2007) that is, it lies within the range of 6.5 and 8.5. Abnormally low $\mathrm{pHs}$ are not common in Nigeria, high $\mathrm{pH}$ 's above 8.5 are often caused by high bicarbonate $\left(\mathrm{HCO}_{3}{ }^{-}\right)$and carbonate $\left(\mathrm{CO}_{3}{ }^{2-}\right)$ concentrations, known as alkalinity. High carbonates cause calcium and magnesium ions to form insoluble minerals leaving sodium as the dominant ion in solution. Extremes of $\mathrm{pH}$ can affect the palatability of water. $\mathrm{pH}$ value govern the behaviours of several other important parameters of water quality (Musa et al., 2003).

\subsubsection{Electrical Conductivity}

The mean and standard deviation of the electrical conductivity of the water samples are masna 39.60 $\pm 0.50 \mu \mathrm{S} / \mathrm{cm}$, An'najeeb $20.00 \pm 0.00 \mu \mathrm{S} / \mathrm{cm}$, Wikki $40.00 \pm 0.5 \mu \mathrm{S} / \mathrm{cm}$, Basfrost $14.00 \pm 0.00 \mu \mathrm{S} / \mathrm{cm}$, Summaye $50 \pm 0.57 \mu \mathrm{S} / \mathrm{cm}$ and Loyal $17.30 \pm 0.76 \mu \mathrm{S} / \mathrm{cm}$ and were all within the acceptable range of 
$1000 \mu \mathrm{S} / \mathrm{cm}$ as given by the Nigeria standard for drinking water quality and WHO (2007). Electrical conductivity (EC) in natural waters is the normalized measure of the water's ability to conduct electric current. However high value of conductivity is mostly influenced by dissolved salts such as sodium chloride and potassium chloride or sulphate (Orebiyi et al., 2010). High conductivity in any sample might have also been caused by the presence of some metallic ore bodies in the area where the borehole wells used for the sachet water are dug. Electric conductivity is a useful tool to assess the purity of water.

\subsubsection{Total Dissolved Solids (TDS)}

The mean and standard deviation of the water samples ranges from $10.00 \pm 0.00-85 \pm 0.57 \mathrm{mg} / \mathrm{L}$. The samples analyzed were all within the recommendable limit of $500 \mathrm{mg} / \mathrm{L}$ of the Nigeria standard for drinking water quality and WHO (2007).

TDS can be taken as an indicator for the general water quality because it directly affects the aesthetic value of the water by increasing turbidity. High concentrations of TDS limit the suitability of water as a drinking source. Therefore the drinking water is safe in terms of TDS.

\subsubsection{Temperature}

The mean and standard deviation of the temperature of the water samples obtained ranges from $26.60 \pm 0.21-28.33 \pm 0.98^{\circ} \mathrm{C}$. Though not defined by Nigerian Standard for Drinking Water Quality and WHO (2007), the temperature values are only slightly above normal room temperature as of the time of samples collection. The temperature is being influenced by solar radiation.

\subsubsection{Turbidity}

Turbidity mean and standard deviation values of the water samples ranges from $0.00-2.00 \pm 0.00 \mathrm{NTU}$, whereas the recommended limit value given by Nigeria standard for drinking water quality and WHO (2007) is 5NTU. In terms of turbidity the sachet water samples are fit for drinking. The existence of turbidity in water affects its acceptability to consumers thus clarity of water is said to be a major factor in consumer satisfaction (EPA, 2001). Thus turbidity decreases clarity of water and result from the finely divided impurities regardless of sources from which it may be present in water. Turbidity has been used over many years as an indicator of drinking water quality and as an indicator of the efficiency of drinking water coagulation and filtration processes. Turbidity has been described as a relatively crude method of detecting a wide variety of particles from a wide assortment of sources as it provides no information about the nature of the particles. High turbidity in water is caused by the presence of colloidal and suspended matter (such as clay, silt, finely divided organic and inorganic matter, plankton, and other microscopic organisms) (Ayoade and Ibitoye, 2012). The added presence of turbidity increases the apparent, but not the true colour of water.

\subsubsection{Total Hardness}

Total water hardness occurs as a result of the presence of magnesium ions and calcium ions in a water sample. The values obtained ranges from $0-40 \mathrm{mg} / \mathrm{L}$ which were all within the limit recommended by the Nigeria standard for drinking water quality (2011).Masna and An'najeeb were found to be 0 , surprisingly a value was obtained for magnesium for these samples. The total hardness was determined by titrimetric method involving the chelating of $\mathrm{Mg}^{2+}$ ions species present in the water samples, as such only the inorganic $\mathrm{Mg}^{2+}$ ion presence apart from been taken into consideration will be accounted for. On the other hand the elemental analysis for $\mathrm{Mg}^{2+}$ by the AAS which involved the conversion of all species first into their ionic state by the process of digestion does ensure that all metals whether present in organic or inorganic can be taken into consideration and accounted for. Hence it is possible that the process involved in the production of water was very effective and efficient in the total removal of any form of hardness in the water samples. It was less more effective in eliminating all sources of organic magnesium ion from water sample.

\subsubsection{Chloride}

The mean and standard deviation of Chloride ion concentration for all the water samples ranged from of $7.80 \pm 0.20-20.30 \pm 0.4 \mathrm{mg} / \mathrm{L}$ which was below the permissible limit of $250 \mathrm{mg} / \mathrm{L}$ as given by the Nigeria standard for drinking water quality (2011) and WHO (2011). This may imply that all the water from these sources is suitable for drinking. 
The concentration of chloride is the indicator of sewage pollution, fertilizers, industrial waste and also imparts laxative effect. Atmospheric sources or sea water contamination is reason for bulk of the chloride concentration in groundwater which may exceed due to base-exchange phenomena, high temperature, domestic effluents, septic tanks and low rainfall (Arghyam 1991). Porous soil and permeability also plays a key role in building up the chlorides concentration (Chanda et.al 1999). Chloride concentrations in excess of about $250 \mathrm{mg} / \mathrm{L}$ can give rise to detestable taste in water (Ekpete, 2002).

\subsubsection{Lead}

All the samples analyzed were higher than the standard permissible limit of $0.001 \mathrm{mg} / \mathrm{L}$ given by the Nigeria standard for drinking water quality(2007) and WHO(2011), with Summaye having the highest mean value of $0.3 \mathrm{mg} / \mathrm{L}$. Lead in water can be linked to the effect of run-off from contaminated land area where the water source for the water plant is located, infiltration activities from sewage from effluents which moves down to form the underground water which is source of borehole used for sachet water.

\subsubsection{Iron}

The result obtained from the analyses carried out on the water samples indicated that the iron concentration of the sachet waters samples were slightly above the standard value of $0.3 \mathrm{mg} / \mathrm{L}$ recommended by the Nigeria standard for drinking water quality (2007) and the WHO (2007). The value ranges from a mean value of $0.32 \pm 0.01-1.01 \pm 0.05 \mathrm{mg} / \mathrm{L}$. Loyal sachet water had the highest value of $1.01 \mathrm{mg} / \mathrm{L}$ while Summaye sachet water had the lowest value of $0.326 \mathrm{mg} / \mathrm{L}$.

The higher iron concentration was attributed to rainfall infiltration into the soil and underlying geological formations which dissolve iron, causing it to sleep into aquifers that serve as a source of underground water. Iron is not considered hazardous to health. In fact, instead it is an essential element for good health because it transports oxygen in the blood. Iron is considered a secondary or aesthetic contaminant (WHO, 2004), thus since the values obtained are just slightly above the standard it could also be considered fit for drinking since it does not actually have a negative effect in the body.

\subsubsection{Copper}

The result obtained from the analyses carried out on the samples indicated that all where within the standard value of $1.00 \mathrm{mg} / \mathrm{L}$ recommended by the Nigeria standard for drinking water quality (2007) and $1.3 \mathrm{mg} / \mathrm{L}$ by WHO (2007) however, Masna and basfrost water samples with the observed value of $2.63 \pm 0.00$ and $4.00 \pm 0.02 \mathrm{mg} / \mathrm{L}$ respectively were above the recommended standard.

Copper is commonly found in drinking water (U.S. Environmental Protection Agency, 1985a) thus found in surface water and in some underground water. Copper is an essential element in human metabolism, and it is well-known that deficiency results in a variety of clinical disorders, including nutritional anaemia in infants, skeletal defects, nervous system degeneration, and reproductive abnormalities.. Although the intake of large doses of copper has resulted in adverse health effects such as gastrointestinal disorder. The levels at which this occurs are much higher than the aesthetic objective (Health Canada, 1992).

\subsubsection{Chromium}

Primary sources of chromium in water is usually from human activities such as mining, water from electroplating operations, which is not a practice in the site where the plant is located, and garbage or refuse dump in the sites where the plant is located. The mean value of all the samples obtained ranges from $0.05 \pm 0.00-0.16 \pm 0.16 \mathrm{mg} / \mathrm{L}$ which were slightly above the recommended value of $0.05 \mathrm{mg} / \mathrm{l}$ of the Nigeria standard for drinking water quality (2007) and WHO (2007) except for Loyal water sample which was within the range with a value of $0.05 \mathrm{mg} / \mathrm{L}$. The higher values of chromium could be linked to the rate of run-off and infiltration activities within the various plant locations.

Chromium in excess is toxic thus leading to liver and kidney damage, internal hemorrhage, and respiratory disorders, as well as causing cancer in humans and animals through inhalation exposure, but it has not been shown to be carcinogenic through ingestion exposure (U.S. Environmental Protection Agency, 1985a; U.S. Environmental Protection Agency, 1991e)

\subsubsection{Magnesium}

The mean value obtained ranges from $1.08 \pm 0.02-5.86 \pm 0.09 \mathrm{mg} / \mathrm{L}$. these values fell within the permissible limit of 30mg/L recommended by the WHO (2011) and Nigeria standard for drinking water 
quality (2007). Magnesium is the $8^{\text {th }}$ most abundant element on earth crust and natural constituent of water. It is an essential for proper functioning of living organisms and found in minerals like dolomite, magnesite etc. Human body contains about $25 \mathrm{~g}$ of magnesium $(60 \%$ in bones and $40 \%$ in muscles and tissues). Excess magnesium concentration may lead to changes in mental status, loss of appetite, muscles weakness extremely low blood pressure, irregular heart beat.

\subsubsection{Potassium}

Potassium is silver white alkali which is highly reactive with water. Potassium is necessary for living organism functioning hence found in all human and animal tissues particularly in plants cells. The total potassium amount in human body lies between 110 to $140 \mathrm{~g}$. It is vital for human body functions like heart protection, regulation of blood pressure, protein dissolution, muscle contraction, nerve stimulus etc. Potassium is deficient in rare but may led to depression, muscle weakness, heart rhythm disorder etc. According to WHO standards the permissible limit of potassium is $12 \mathrm{mg} / \mathrm{L}$. Results show that the concentration of potassium in the sachet water analyzed ranges from mean value of $1.00 \pm 0.00$ $6.70 \pm 0.30 \mathrm{in} \mathrm{mg} / \mathrm{L}$. These results met the $\mathrm{WHO}$ standards and may become preventive from diseases associated from potassium extreme deficiency.

\subsubsection{Nitrite}

The mean value that was determined for the water samples ranges from $0.002 \pm 0.00-0.014 \pm 0.003 \mathrm{mg} / \mathrm{L}$. The results obtained were within $0.2 \mathrm{mg} / \mathrm{L}$ limit of the Nigeria standard for drinking water quality (2007) and WHO (2007). Fertilizer, human and animal waste are some of the sources of nitrite contamination of ground water. Elevated nitrites level may suggest the possible presence of other contaminants such as disease causing organisms, pesticides or other inorganic and organic compounds that could cause health hazard. Nitrite levels at or above this level have been known to cause a potentially fatal blood disorder in infants under six months of age called methemoglobinemia or blue baby syndrome in which there is a reduction in the oxygen carrying capacity of blood (Musa et al., 2013).

\subsection{Bacteriological Analysis}

The results of the bacteriological analyses of the water samples carried out was zero (0) that is no growth was found thus bacteria and E. coli were not detected in the water samples, indicating no feacal pollution of the underground water source and water depots which can be attributed to an effective quality control system and a high level of sanitation in all the production depots

\section{CONCLUSION}

The analyses carried out showed that all the physical parameters, bacteriological parameters and anions content in the water samples were within the standards that was recommended by the WHO and Nigeria standard for drinking water quality. But some of the metals determined were slightly above the standard. Based on the analyses and the results, it could be concluded that the physicochemical and bacteriological parameters in sachets water consumed in Bauchi metropolis conformed to the WHO recommended standards for potable water and that the consumption of the sachets water may not pose health hazards to the consumers at the time of the study, except for some metal such as copper whose concentration was slightly above standard in Masna and Basfrost water sample, for lead and iron all the samples were slightly above the limit and for chromium Loyal water sample was within the limit but the other samples were slightly above the limit recommended by Nigeria standard for drinking water quality and WHO which may pose health hazard to consumers. Since the analyzed parameters may cause great health problems to humans at concentrations greater than the recommended standards, it is recommended that the levels of the studied parameters in sachets water obtained in the studied area and its environment be constantly monitored in order to ascertain the suitability of such water for human consumption.

\section{REFERENCES}

Adefemi S. O. and Awokunmi E. E. (2010). Determination of physico-chemical parameters and heavy metals in water samples from Itaogbolu area of Ondo-State, Nigeria, African Journal of Environmental Science and Technology, 4(3), pp 145-148.

Adeyeye, E. (1994). Determination of heavy metals in Illisha Africana, associated Water, Soil Sediments from some fish ponds, International Journal of Environmental Study, 45, pp 231-240.

APHA standard methods for examination of water and waste water, American Public health Association, Washington D.C. (1998). 
Anon, J. (1980). Government of Malawi national water policy. Ministry of water development. Lilongwe: Capital Printing.

Arghyam, N. (1991).Indian Standards for Drinking Water. Bureau of Indian Standards, New Delhi, India, IS: 10500.

Asonye, C.C., Okolie, N.P. and Okenwa, E.E. (2007). Some physic-chemical characteristics and heavy metal profiles of Nigeria rivers, streams and waterways. African Journal of biotechnology 6(5): 617-624.

Augoustinos, M.T., Grabow, N.A. and Genthe, B. (1993). An improved membrane filtration method for enumeration of faecal coliforms and E. coli by a fluorogenic $\beta$-glucuronidase assay. Water Scientific Technology, 27, 267-270.

Aulicino, F. A. and Orsini, P. (1996). Presence of biofilm in a drinking water system in Pie- mont. L'igiene Moderna, 150, 29-40.

Ayoade P.A. and Ibitoye T.A. (2012). Appraisal of water quality status within Ilesha Environs, South -Western Nigeria. J Emerging Trends Eng Appl Sci, 3(6):969-976.

Chanda D.K. (1999). Hydrology Journal 7: 431-439.

Balogun, I. I., Akoteyon, I. S., and Adeaga, O. (2012). Evaluating Land Use Effects on Groundwater Quality in Lagos-Nigeria Using Water Quality Index. Journal of Scientific Research; J. Sci. Res. 4 (2), 397-409

Bauchi State-Online Nigeria.com. 29 January 2003. Retrieved from www.online Nigeria.com/Bauchi State

Ekpete,O.A.(2002). Determination of physicochemical parameters in borehole water in odihologboji community in Rivers state. Afr. J. Interdiscp. Stud.., 3(1): 23-27

EPA, (2001). Parameters of water quality: Interpretations and Standards. A publication of Ireland Environmental Protection Agency.

Hamil, L. and Bell, F.G., (1998). Ground water Resources development. D.L.C. 8(5):107-489.

Health Canada, (1992). Environment and Workplace. Report on water quality. Copper. http://www.hcsc.gc.ca/ewh-semt/pubs/water-eau/copper-cuivre/ index-eng.php. Date accessed 30/3/2014.

Musa,J.J. and Ahanonu J.J. (2013). Quality of shallow selected Agarian communities in patigi locial government area, Nigeria. International Journal of Basic and applied science. 1(3): 548-563.

Mustapha, K. M., (2008). Assessment of water quality of Oyun Reservoir, Offa, Nigeria, using selected physicchemical parameters. Turkish Journal of Fisheries and Aquatic Sciences 8: 309-319

Nigerian Standard for Drinking Water Quality, Parameters and Maximum allowable limits, Nigerian Industrial Standards, 15-17 (2011)

Reda. A, (2016). Physiochemical analysis of drinking water quality of Arabaminch town Journal of environmental and analytical toxicology, 6:356.

U.S. Environmental Protection Agency (1985a). National Primary and Secondary Drinking Water Regulations; Synthetic Organic Chemicals, Inorganic Chemicals and Microorganisms. Federal Register, 50: 4693647022.

U.S. Environmental Protection Agency (1991e), National Primary and Secondary Drinking Water Regulations; Synthetic Organic Chemicals and Inorganic Chemicals; Monitoring for Unregulated Contaminants; National Primary Drinking Water Regulations Implementation; National Secondary Drinking Water Regulations. Federal Register, 56: 3526-3599.

WHO and UNICEF, (2003). Global Strategy for Infantand Young Child Feeding. World Health Organization, Geneva.

WHO, (2004). World Health Organization guidelines for drinking water quality Vol. 1

WHO, (2007). pH in Drinking Water: Background Document for Preparation of WHO Guidelines for drinking water Quality.

WHO, (2011). Manganese in drinking water. Background document for development of WHO Guidelines for Drinking-water Quality.

Citation: M. Shibdawa et al., "Physicochemical Analysis of Some Table Water in Bauchi Metropolis", International Journal of Advanced Research in Chemical Science (IJARCS), vol. 5, no. 6, pp. 7-14, 2018. http://dx.doi.org/10.20431/2349-0403.0506002

Copyright: (C) 2018 Authors. This is an open-access article distributed under the terms of the Creative Commons Attribution License, which permits unrestricted use, distribution, and reproduction in any medium, provided the original author and source are credited. 